\title{
Increased plasma plasminogen activator inhibitor 1 levels. A possible link between insulin resistance and atherothrombosis
}

\author{
I.Juhan-Vague ${ }^{1}$, M.C. Alessi ${ }^{1}$ and P. Vague ${ }^{2}$ \\ ' Laboratory of Haematology, ${ }^{2}$ Department of Diabetology, CHU Timone, Marseille, France
}

\begin{abstract}
Summary. According to recent prospective studies, hypofibrinolysis due to elevated plasma plasminogen activator inhibitor 1 levels appears to be an independent risk factor for myocardial reinfarction in men, and hyperinsulinaemia, a major indicator of insulin resistance is considered as a risk factor for coronary disease. It has recently been shown that insulin resistance is accompanied by an increased plasma plasminogen activator inhibitor 1 concentration: A significant correlation coefficient was demonstrated between plasminogen activator inhibitor 1 and fasting plasma insulin in the normal population, in obese subjects, in Type 2 (non-insulin-dependent) diabetic patients and in angina pectoris. Attempts to decrease insulin resistance such as fasting, diet, or administration of an oral anti-diabetic drug such as Metformin induced a parallel decrease in plasma insulin and plasminogen activator inhibitor 1 levels. This inhibitor is produced by endothelial cells and by hepatocytes in culture.
\end{abstract}

Plasminogen activator inhibitor 1 synthesis by hepatocytes in culture was stimulated by an increasing insulin concentration, or low density lipoproteins, whereas the endothelial cell synthesis was stimulated by very low density lipoproteins especially when they were obtained from hypertriglyceridaemic patients. Therefore, a direct effect of insulin or lipoprotein changes on the cells which synthesize plasminogen activator inhibitor 1 could be responsible for its increased plasma concentration in insulin resistance states. The increase in plasma plasminogen activator inhibitor 1 levels linked to hyperinsulinaemia is a tempting partial explanation for the association between insulin resistance and coronary disease.

Key words: Plasminogen activator inhibitor 1 , fibrinolysis, atherosclerosis, arterial thrombosis, insulin, insulin resistance, low density lipoprotein, hepatocytes, endothelial cells.
Clinical manifestations of coronary artery disease result from the progressive development of atherosclerotic plaque and subsequent thrombus formation. The role of arterial fibrin deposit in the occlusion of coronary arteries that leads to myocardial infarction is obvious. More subtly, however, fibrin deposit could play a role in the development of atherosclerotic lesions possibly as an initiating factor of endothelial cell injury. Fibrin is a consistent component of human atherosclerotic plaque and it may contribute to plaque growth by stimulation of cell proliferation and by the binding and accumulation of low density lipoprotein [1-4].

Since it leads to the decreased removal of fibrin deposit, hypofibrinolysis would be a prime candidate for a role in the initiation and development of atherothrombosis. Recent findings showed that deficient fibrinolysis is mostly due to the increase in plasma plasminogen activator inhibitor 1 (PAI-1) [5], (Fig. 1). In recent years several studies have demonstrated high plasma PAI-1 in patients with coronary artery disease [6-15] and this appears to be an independent risk factor for myocardial reinfarction within 3 years in men under 45 years-of-age [16-18]. To date no correlation has been demonstrated between PAI1 levels and the extension of coronary lesions in cross-sectional studies $[6,8,10,13,19]$. However, in a recent prospective study, some relationship was observed in patients presenting previous myocardial infarction who were subjected to a glucose tolerance test 3 to 6 months after the acute event and reangiographically assessed 4 to 7 years after the first catheterisation. PAI- 1 level was the best predictor of disease progression of coronary atherosclerosis in patients with glucose intolérance [20].

Hyperinsulinaemia is a major indicator of insulin resistance which is associated with several disorders. Grouped under the term "syndrome X" [21], these abnormalities include the following: impaired glucose tolerance, increased blood pressure, modifications of the lipoprotein pattern with increased VLDL triglyceride and decreased HDL cholesterol. This syndrome is mainly observed in subjects with excessive body weight and fat dis- 


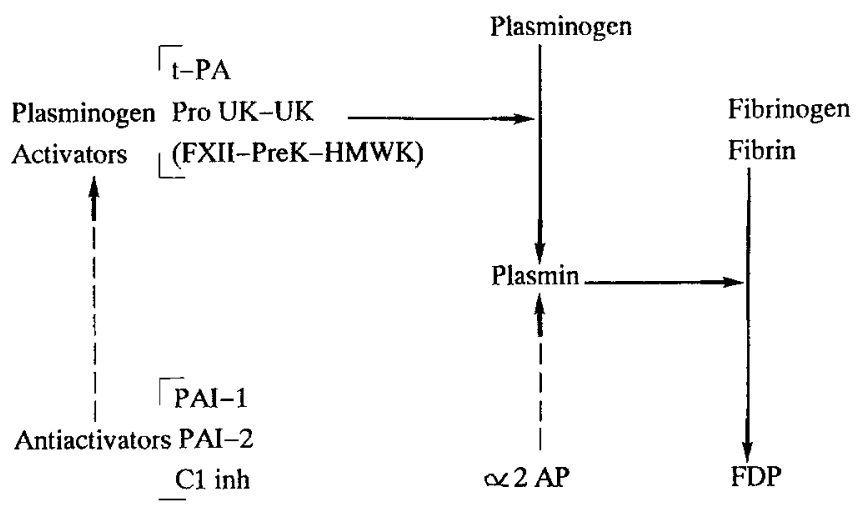

Fig. 1. The fibrinolytic system. t-PA: Tissue-type plasminogen activator, UK: Urokinase, FXII: Factor XII, Pre K: Prekallicrein, HMWK: High molecular weight kininogen, PAI: Plasminogen activator inhibitor, $\mathrm{CI}$ inh: $\mathrm{CI}$ inhibitor, $\alpha 2 \mathrm{AP}: \alpha 2$-antiplasmin, FDP: Fibrinogen degradation products

tribution predominant at the upper part of the body $[22,23]$. Hyperinsulinaemia is considered as a risk factor for myocardial infarction $[24,25]$ according to three prospective studies [26-28].

Our group has shown that insulin resistance is accompanied by increased plasma PAI- 1 concentration $[14,29$ 32]. A tempting implication of this finding is that hypofibrinolysis due to a high PAI-1 level contributes to the pathogenic role of the insulin resistant state in coronary artery disease. This paper discusses the relationship between insulin resistance and plasma PAI-1 concentration.

\section{Increased plasma PAI-1 concentration and insulin resistance. Cross-sectional studies}

More than 20 years ago hypofibrinolysis was shown to be associated with obesity [33-36], hypertriglyceridaemia $[37,38]$ and diabetes $[39,40]$. This defect has recently been attributed to the increased plasma concentration of PAI-1 accompanying these disorders: Several studies have shown that a very significant correlation exists between PAI-1 concentration and body mass index $[14,29-32,41-$ 48] waist-to-hip circumference ratio which estimates body fat distribution $[31,43,46-48]$ or triglyceride level $[8,16$, $18,30,43,47,49-51]$. Increased PAI-1 levels have also been reported in non-insulin-dependent diabetic subjects but insulin-dependent diabetic patients had a nearly normal level of PAI-1 $[32,41,44,52,53]$. PAI- 1 was also higher in untreated mildly hypertensive men compared to control subjects [51], and PAI activity was correlated with systolic blood pressure in angina pectoris [14].

The relationship between PAI- 1 and fasting insulin levels was first demonstrated by our group [29] in normal subjects with a wide range of body weight. We have also observed this relationship in several groups of subjects including non-diabetic obese women [30,31], Type 2 diabetic patients [32] and patients with angina pectoris [14] (Table 1). Similar observations have been reported by Legnani et al. in obese children [42], by Sundell et al. in subjects fed a low carbohydrate diet [43] and, by Landin et al. in obese women [48], and in non-obese hypertensive men [51].

In all of our studies the correlation coefficient between PAI-1 and insulin was around $0.6(p<0.001)$ (Table 1$)$. As previously mentioned the PAI-1 concentration was also correlated with body mass index [29-31], waist-to-hip circumference ratio [31], plasma triglyceride level [14, 31], or apolipoprotein B [32]. Multiple regression analysis has shown that in most cases these correlations disappeared after adjustment for insulin [14, 29, 31, 32]. However, a weak relationship subsisted between triglyceride and PAI-1 in pre-menopausal obese women [31]. These findings suggest that the link between plasma insulin and PAI1 levels is independent of the other risk factors and that the relationship between PAI-1 level on the one hand and body mass index, waist-to-hip circumference ratio and perhaps triglyceride on the other could depend on the relationship between PAI-1 and insulin, this latter being a witness of the insulin-resistance state.

The association between plasma insulin and PAI- 1 levels has not been consistently found $[16,18,47]$. This is probably due to the use of various insulinogenic indexes or parameters of insulin secretion. Plasma insulin may be measured either in the fasting state or after stimulation e. g. glucose load. In non-diabetic subjects, fasting plasma insulin levels are closely related to the degree of insulin resistance [21] while the insulin response to a glucose load depends on both the degree of insulin resistance and the ability of the Beta cell to cope with the stimulus. In a voluntarily heterogenous group of 39 non-diabetic subjects (27 with normal glucose tolerance, 12 with impaired glucose tolerance, ages ranging from 11 to 61 years and body mass index from 17 to 44 ) we still observed a statistically significant relationship between PAI- 1 level and fasting insulin $(r=0.38 ; p<0.02)$. Conversely the relationship between PAI-1 and other parameters of insulin secretion (insulin sum, insulin increment, insulin area) disappeared or were less significant (insulin at 120 min was correlated with PAI-1) $(r=0.33 ; p<0.04)$.

In fasting non-diabetic subjects insulin is accompanied in the plasma by insulin precursors, proinsulin, split proinsulin, in a molar ratio of $0.15[54,55]$ and may be as high as 0.25 [56]. These precursors may contaminate the immunoreactive insulin data according to the degree they crossreact with the polyclonal antibody used. However, a contamination of $25 \%$ or less (if the cross-reaction is limited as in many insulin assay kits) would have only a limited ef-

Table 1. Coefficient of correlation ( $r$ ) between plasminogen activator inhibitor 1 (PAI-1) and insulinaemia, triglyceride, body mass index, in various groups of subjects

\begin{tabular}{llll}
\hline$r$ & PAI-1/ & PAI-1/ & PAI-1/ \\
& Ins & TG & BMI \\
\hline Normal subjects [29] & $0.52^{c}$ & 0.16 & $0.66^{c}$ \\
Obese non-diabetic women [31] & $0.72^{c}$ & $0.56^{c}$ & $0.50^{c}$ \\
Type 2 diabetic patients [32] & $0.60^{c}$ & 0.31 & $0.31^{\mathrm{a}}$ \\
Angina pectoris [14] & $0.59^{c}$ & $0.25^{\mathrm{a}}$ & $0.39^{\mathrm{b}}$ \\
\hline
\end{tabular}

${ }^{\mathrm{a}} p<0.05,{ }^{\mathrm{b}} p<0.01,{ }^{\mathrm{c}} p<0.001$

Ins: Insulin, TG: Triglyceride, BMI: Body mass index (weight $[\mathrm{kg}] /$ height $\left[\mathrm{m}^{2}\right]$ ) 
fect on a close relationship such as the one generally observed between fasting insulin and PAI-1 levels. But in Type 2 diabetic patients, the proportion of precursors is higher and in one study [57] PAI-1 was found to correlate with 32-33 split proinsulin and not with insulin. The interpretation of this finding remains speculative.

\section{Increased plasma PAI-1 concentration and insulin resistance. Intervention studies}

The link between insulin resistance and PAI-1 levels observed in cross-sectional studies was confirmed in intervention studies aimed at reducing insulin resistance. The effects of decreasing plasma insulin on PAI-1 levels have been analysed in several studies. It was first shown that a simultaneous drop in insulin, triglyceride and PAI-1 levels was observed in 10 obese women after a $24 \mathrm{~h}$ fasting period [29]. The oral anti-diabetic drug Metformin which is known to have a hypoglycaemic effect by improving sensitivity to insulin [58] was shown several years ago to enhance fibrinolytic activity [59]. This effect could be explained by a decrease in PAI-1 level [60]. In a 15 day double-blind placebo study using Metformin (1.7 g/day) in non-diabetic obese women, we observed a decrease in fasting plasma insulin, triglyceride as well as PAI-1 levels in the treated group but not in the placebo group [60].

Since weight loss improves the insulin resistance of obese subjects [61], it should also lead to a decrease in PAI-1. We observed the evolution of PAI-1 over a severalmonth period in a 21-year-old obese woman who had suffered cerebral venous thrombosis, after losing weight on a low-caloric diet, the normalization of plasma insulin and triglyceride was accompanied by the normalization of PAI-1 levels [50]. Similar changes in PAI-1 have been reported after 2 weeks [45], 6 weeks [62] or 13 weeks [63] hypocaloric diet. These findings are in agreement with those of Andersen [38] and Simpson [64] who observed increased fibrinolytic activity in high risk male coronary patients after diet and clofibrate therapy aimed at normalizing triglyceride level.

The beneficial effect of physical exercise on insulin resistance is well-known [65], and it has been shown that physical training also improves fibrinolytic activity $[64,66]$. It was recently demonstrated that the increase in fibrinolytic activity after physical training was due to a decrease in PAI-1 levels $[67,68]$.

\section{Attemps at explaining the increased plasma PAI-1 levels in insulin resistance}

The existence of a significant correlation between plasma PAI-1 and insulin concentration, the simultaneous variations of these two parameters in intervention studies aimed at reducing the insulin level suggest that insulin may act directly or indirectly on the cells which synthesize PAI-1 i.e. endothelial cells and hepatocytes $[69,70]$.

Our group showed [71] that adding insulin to umbilical vein endothelial cell culture had no effect on PAI-1 synthesis. In contrast, insulin at $0.6^{-9}$ molar concentration in- duced after $24 \mathrm{~h}$ a two-fold increase in PAI-1 production by the hepatocyte cell line HepG2. This concentration of insulin is similar to the one found in the portal vein after meals. This effect seems to be specific for PAI-1 since the synthesis of other proteins of hepatic origin, e.g. fibrinogen or $\alpha 2$-antiplasmin was not modified. This insulin effect was reproduced in human hepatocytes in culture and was accompanied by an increase in PAI-1 mRNA [72]. Similar results were obtained by adding insulin-like growth factor 1 (IGF-1) to HepG2 cells [73]. The fact that the DNA content was not modified after insulin or the addition of IGF-1 to the cells excludes a proliferative effect at the concentrations used.

The stimulating effect of insulin on PAI-1 synthesis by HepG2 cells was abolished when the anti-diabetic drug Metformin was added to the cell cultures at the same time as insulin (unpublished data). This inhibitory effect of Metformin was dose-dependent being significant at $10^{-6}$ molar concentration. Therefore, the insulin added to hepatocytes in culture stimulated their production of PAI-1 and this effect was abolished by Metformin.

In vivo this direct effect on PAI-1 production by the liver was not observed after acute administration of insulin $[74,75]$. Even with a hyperinsulinaemic glucose clamp for $24 \mathrm{~h} \mathrm{[76]} \mathrm{we} \mathrm{failed} \mathrm{to} \mathrm{increase} \mathrm{PAI-} 1$ levels or to break down the well-known circadian rhythm of PAI-1 levels which shows a peak in the early morning and a nadir in the afternoon [77]. Medvescek et al. [78] studied the effect of the acute rise in endogenous insulin following an oral glucose load. It induced a discrete transitory increase in PAI-1 levels one hour after the peak of insulinaemia. This effect did not mask the diurnal decline in PAI-1 and was similar in lean and obese subjects.

PAI-1 concentration in plasma is therefore not directly related to insulin level at least under acute conditions which are not accompanied by insulin resistance or sustained non-esterified fatty acid flux. Thus, a discrepancy exists between in vitro and in vivo data concerning direct effects of insulin on PAI-1 levels. One hypothesis to explain this discrepancy is that the cells in culture present insulin resistance, which mimics the in vivo conditions of insulin resistance. This hypothesis is supported by the fact that HepG2 cells possess defective insulin receptors on the membrane surface [79]. Furthermore, adding Metformin along with insulin to insulin resistant rat hepatocytes restored normal lipogenesis [80].

The mechanism by which insulin influences the release of PAI-1 may be either direct or indirect through modification in plasma lipoproteins. Given its effects on hepatic synthesis of VLDL triglyceride [81], insulin could also act indirectly by quantitative or qualitative changes of lipoproteins. Interestingly Stiko-Rahm et al. [82] showed that purified VLDL stimulate PAI-1 secretion by endothelial cells from umbilical vein and that VLDL from hypertriglyceridaemic subjects were more potent than VLDL from normotriglyceridaemic patients, the large particle subfraction was observed to produce the greater PAI-1 release. The stimulating effect of VLDL was dependent on binding of the lipoprotein particles to apolipoprotein $\mathrm{B} / \mathrm{E}$ receptors of the cells as the effect was abolished in presence of an antibody against the apolipoprotein $\mathrm{B} / \mathrm{E}$ receptors. 
Another argument for the role of circulating lipid levels in regulating PAI-1 concentration is that we have shown strong stimulation of the hepatocyte synthesis of PAI-1 by normal non-oxidized LDL [83], this effect being dependent of the binding of LDL to the apolipoprotein $\mathrm{B} / \mathrm{E}$ receptors.

Taken together these in vitro data strongly indicate that PAI-1 synthesis by both hepatocytes and endothelial cells could be affected by high insulin concentration and lipoprotein abnormalities in patients with insulin-resistance states.

\section{Conclusion}

Insulin resistance may increase the risk of coronary disease by promoting the formation of atheromatous lesions and development of thrombosis. A defect in the fibrinolytic system could be responsible for the initiation and the late complications of atherothrombosis. The increase in PAI-1 concentration linked to hyperinsulinaemia is a tempting partial explanation for the association between insulin resistance and coronary disease.

Normalization of PAI- 1 by reducing insulin resistance could slow down atherothrombosis and prevent coronary disease. Further epidemiologic and intervention data are needed to confirm this hypothesis.

\section{References}

1. Duguid JB (1946) Thrombosis as a factor in the pathogenesis of coronary atherosclerosis. J Pathol Bacteriol 58: 207-212

2. Schwartz CJ, Valente AJ, Kelley JL, Sprague EA, Edwards EH (1988) Thrombosis and the development of atherosclerosis: Rokitansky revisited. Semin Thromb Hemostas 14: 189-195

3. Bini A, Fenoglio JJ, Sobel J, Owen J, Fejgl M, Kaplan KK (1987) Immunochemical characterization of fibrinogen, fibrin I and fibrin II in human thrombi and atherosclerotic lesions. Blood 69 : $1038-1045$

4. Thompson WD, Smith EB (1989) Atherosclerosis and the coagulation system. J Pathol 159: 97-106

5. Wiman B, Hamsten A (1990) The fibrinolytic enzyme system and its role in the etiology of thrombo-embolic disease. Semin Thromb Haemostasis 26: 207-216

6. Paramo JA, Colucci M, Collen D, van der Werf F (1985) Plasminogen activator inhibitor in the blood of patients with coronary artery disease. $\mathrm{Br}$ Med $\mathbf{J} 291: 575-576$

7. Almer LO, Ohlin H (1987) Elevated levels of the rapid inhibition of plasminogen activator ( $\mathrm{t}-\mathrm{PA}$ ) in acute myocardial infarction. Thromb Res 47: 335-339

8. Mehta J, Mehta P, Lawson D, Saldeen T (1987). Plasma tissue plasminogen activator inhibitor levels in coronary artery disease: correlation with age and serum triglyceride concentrations. J Am Coll Cardiol 9:263-268

9. Nilsson TK, Johnson O (1987) The extrinsic fibrinolytic system in survivors of myocardial infarction. Thromb Res 48: 621-630

10. Verheugt FWA, Ten Cate JA, Sturk A, Imandt L, Verhorst MJ, van Eenige MJ, Verwey W, Roos JP (1987) Tissue plasminogen activator activity and inhibition in acute myocardial infarction and angiographically normal coronary arteries. Am J Cardiol 59: 1075-1079

11. Aznar J, Estelles A, Tormo G, Sapena P, Tormo V, Blanch S, Espana F (1988) Plasminogen activator inhibitor activity and other fibrinolytic variables in patients with coronary artery disease. $\mathrm{Br}$ Heart J 59: 535-541
12. Francis RB, Kawanishi D, Baruch T, Mahrer P, Rahimtoola S, Feinstein DI (1988) Impaired fibrinolysis in coronary artery disease. Am Heart J 115: 776-780

13. Huber K, Rosc D, Resch I, Schuster E, Glogar DH, Kaindl F, Binder BR (1988) Circadian fluctuations of plasminogen activator inhibitor and tissue plasminogen activator levels in plasma of patients with unstable coronary artery disease and acute myocardial infarction. Thromb Haemostas 60: 372-376

14. Juhan-Vague I, Alessi MC, Joly P, Thirion W, Vague P, Declerck PJ, Serradimigni A, Collen D (1989) Plasma plasminogen activator inhibitor in angina pectoris. Influence of plasma insulin and acute-phase response. Arteriosclerosis 9: 362-367

15. Olofsson BO, Dahlen G, Nilsson TK (1989) Evidence for increased levels of plasminogen activator inhibitor and tissue plasminogen activator in plasma of patients with angiographically verified coronary artery disease. Eur Heart J 10: 77-82

16. Hamsten A, Wiman B, Defaire U, Blomback M(1985) Increased plasma level of a rapid inhibitor of tissue plasminogen activator in young survivors of myocardial infarction. $\mathbf{N}$ Engl $\mathbf{J}$ Med 313: 1557-1563

17. Gram J, Jespersen J, Kluft C, Rijken DC (1987) On the usefulness of fibrinolysis variables in the characterization of a risk group for myocardial reinfarction. Acta Med Scand 221: 149-153

18. Hamsten A, Defaire U, Walldius G, Dahlen G, Szamosi A, Landov C, Blomback M, Wiman B (1987) Plasminogen activator inhibitor in plasma: risk factor for recurrent myocardial infarction. Lancet II: 3-9

19. Oseroff A, Krishnamurti C, Hassett A, Tang D, Alving B (1989) Plasminogen activator and plasminogen activator inhibitor activities in men with coronary artery disease. J Lab Clin Med 113: 88-93

20. Bavenholm P, Efendic S, Wiman B, Landou C, de Faire U, Hamsten A (1990) Relationship of insulin response to glucose challenge to severity and rate of progression of coronary atherosclerosis in young survivors of myocardial infarction. Eur Heart $\mathrm{J} 11$ : [Suppl 178] (Abstract)

21. Reaven GM (1988) Banting lecture 1988. Role of insulin resistance in human disease. Diabetes 37: 1595-1607

22. Vague J (1956) The degree of masculine differentiation of obesities. A factor determining predisposition to diabetes, atherosclerosis, gout and uric calculous disease. Am J Clin Nutr 4:2028

23. Larsson B, Svardsudd K, Welin L, Wilhelmsen L, Bjorntorp P, Tiblin G (1984) Abdominal adipose tissue distribution obesity and risk of cardiovascular disease and death: 13 year follow up of participants in the study of men born in 1913. Br Med J 288: 1401-1404

24. Stout RW, Wallance-Owen J (1979) Insulin and atheroma. Lancet I: $1078-1080$

25. Fontbonne A, Eschwege E (1987) Diabetes, hyperglycaemia, hyperinsulinaemia and atherosclerosis: epidemiological data. Diab Metab 13: 350-353

26. Pyörälâ K (1979) Relationship of glucose tolerance and plasma insulin to the incidence of coronary heart disease. Results from two population studies in Finland. Diab Care 2:131-141

27. Welborn TA, Weame K (1979) Coronary heart disease incidence and cardiovascular mortality in Busselton with reference to glucose and insulin concentrations. Diab Care 2: 154-160

28. Ducimetiere P, Eschwege E, Papoz L, Richard JL, Claude JR, Rosselin G (1980) Relationship of plasma insulin levels to the incidence of myocardial infarction and coronary heart disease mortality in a middle-aged population. Diabetologia 19: 205-210

29. Vague P, Juhan-Vague I, Aillaud MF, Badier C, Viard R, Alessi MC, Collen D (1986) Correlation between blood fibrinolytic activity, plasminogen activator inhibitor level, plasma insulin level and relative body weight in normal and obese subjects. Metabolism 35: 250-253

30. Juhan-Vague I, Vague P, Alessi MC, Badier C, Valadier J, Aillaud MF, Atlan C (1987) Relationships between plasma insulin, triglyceride, body mass index and plasminogen activator inhibitor 1 . Diab Metab 13: 331-336 
31. Vague P, Juhan-Vague I, Chabert V, Alessi MC, Atlan C (1989) Fat distribution and plasminogen activator inhibitor activity in non diabetic obese women. Metabolism 38: 913-915

32. Juhan-Vague I, Roul C, Alessi MC, Ardissone JP, Heim M, Vague $\mathbf{P}$ (1989) Increased plasminogen activator inhibitor activity in non insulin dependent diabetic patients. Relationship with plasma insulin. Thromb Haemostas 61:370-373

33. Shaw DA, McNaughton D (1963) Relationship between blood fibrinolytic activity and body fatness. Lancet I: 352-354

34. Ogston DM, Andrew GM (1964) Fibrinolysis in obesity. Lancet II: 1205-1207

35. Grace CS, Goldrick RB (1968) Fibrinolysis and body build. Interrelationships between blood fibrinolysis, body composition, and parameters of lipid and carbohydrate metabolism. J Atheroscler Res 8: 705-719

36. Almer LO, Janzon L (1975) Low vascular fibrinolytic activity in obesity. Thromb Res 6:171-175

37. Epstein SE, Rosing DR, Brakman P, Redwood DR, Astrup T (1970) Impaired fibrinolytic response to exercise in patients with type IV hyperlipoproteinaemia. Lancet II: 631-634

38. Andersen P, Arnesen H, Hjermann I (1981) Hyperlipoproteinaemia and reduced fibrinolytic activity in healthy coronary highrisk men. Acta Med Scand 209: 199-202

39. Fearnley GR, Chakrabarti R, Avis PR (1963) Blood fibrinolytic activity in diabetes mellitus and its bearing on ischaemic heart disease and obesity. Br Med J 1: 921-923

40. Almer LO, Nilsson IM (1975) On fibrinolysis in diabetes mellitus. Acta Med Scand 198: 101-106

41. Auwerx J, Bouillon R, Collen D, Geboers J (1988) Tissue-type plasminogen activator antigen and plasminogen activator inhibitor in diabetes mellitus. Arteriosclerosis 8: 68-72

42. Legnani C, Maccaferri P, Tonini P, Cassio A, Cacciari E, Coccheri S (1988) Reduced fibrinolytic response in obese children: association with high baseline activity of the fast acting plasminogen activator inhibitor (PAI-1). Fibrinolysis 2: 211-214

43. Sundell IB, Nilsson TK, Hallmans G, Nygren C (1988) The effect on body build, diet and endocrine factors on the extrinsic fibrinolytic system in healthy young women. Scand J Clin Invest 48 : 557-564

44. Grant MB, Fitzgerald C, Guay C, Lottenberg R (1989) Fibrinolytic capacity following stimulation with desmopressin acetate in patients with diabetes mellitus. Metabolism 38: 901-907

45. Sundell IB, Dahlgren S, Ranby M, Lundin E, Stenling R, Nilsson TK (1989) Reduction of elevated plasminogen activator inhibitor levels during modest weight loss. Fibrinolysis $3: 51-53$

46. Sundell IB, Nilsson TK, Ranby M, Hallmans G, Hellsten G (1989) Fibrinolytic variables are related to age, sex, blood pressure, and body build measurements: a cross-sectional study in Norsjö, Sweden. J Clin Epidemiol 42: 719-723

47. Sundell IB, Nilsson TK, Hallmans G, Hellsten G, Dahlen GH (1989) Interrelationships between plasma levels of plasminogen activator inhibitor, tissue plasminogen activator, lipoprotein (a), and established cardiovascular risk factors in a North Swedish population. Atherosclerosis 80: 9--16

48. Landin K, Stigendal L, Eriksson E, Krotkiewski M, Risberg B, Tengborn L, Smith U (1990) Abdominal obesity is associated with an impaired fibrinolytic activity and elevated plasminogen activator inhibitor 1. Metabolism 39: 1044 1048

49. Juhan-Vague I, Valadier J, Alessi MC, Aillaud MF, Ansaldi J, Philip-Joet C, Holvoet P, Serradimigni A, Collen D (1987) Deficient t-PA release and elevated PA Inhibitor levels in patients with spontaneous or recurrent deep venous thrombosis. Thromb Haemostas 57: 67-72

50. Juhan-Vague I, Alessi MC, Fossat C, Valadier J, Aillaud MF, Serradimigni A (1988) Clinical relevance of high PAI-1 level in patients with idiopathic/recurrent deep venous thrombosis. Fibrinolysis 2 [Suppl 2]: 85-88

51. Landin K, Tengborn L, Smith U (1990) Elevated fibrinogen and plasminogen activator (PAI-1) in hypertension are related to metabolic risk factors for cardiovascular disease. J Int Med 227: $273-278$
52. Almer LO (1988) Fibrinolytic disorders in diabetes mellitus. Diab Metab 14: 519-522

53. Gram J, Jespersen J, Kold A (1988) Effects of an oral antidiabetic drug on the fibrinolytic system of blood in insulintreated diabetic patients. Metabolism 37: 937-943

54. Ward WK, Lacava EC, Paquette TL, Beard JC, Wallum BJ, Porte D (1987) Disproportionate elevation of immunoreactive proinsulin in Type 2 (non-insulin-dependent) diabetes mellitus and in experimental insulin resistance. Diabetologia 30:698-702

55. Yoshioka N, Kuzuya T, Matsuda A, Taniguchi M, Iwamoto Y (1988) Serum proinsulin level at fasting and after oral glucose load in patients with Type 2 (non-insulin-dependent) diabetes mellitus. Diabetologia 31: $355-360$

56. Temple RC, Carrington CA, Luzio SD, Owens DR, Schneider AE, Sobey WJ, Hales CN (1989) Insulin deficiency in non insulin dependent diabetes. Lancet II: 293-295

57. Nagi DK, Hendra TJ, Ryle AJ, Cooper TM, Temple RC, Clark PMS, Schneider AE, Hales CN, Yudkin JS (1990) The relationships of concentration of insulin, intact proinsulin and 32-33 split proinsulin with cardiovascular risk factors in Type 2 (non-insulin-dependent) diabetic subjects. Diabetologia 33:532-537

58. Jackson RA, Hawa MI, Jaspan JB, Sim BM, Disilvo L, Featmerbe D, Kurtz AB (1987) Mechanism of Metformin action in non insulin dependent diabetes. Diabetes 36: 632-640

59. Chakrabarti R, Hocking ED, Fearnley GR (1965) Fibrinolytic effect of Metformin in coronary artery disease. Lancet II: 256259

60. Vague P, Juhan-Vague I, Alessi MC, Badier C, Valadier J (1987) Metformin decreases the high plasminogen activator inhibitor capacity, plasma insulin and triglyceride levels in non diabetic obese subjects. Thromb Haemostas 57: 326-328

61. Golay A, Felber JP, Dusmet M, Gomez F, Curchod B, Jequier E (1985) Effect of weight loss on glucose disposal in obese and obese diabetic patients. Int J Obes 9:181-190

62. Mehrabian M, Peter JB, Barnard RJ, Lusis AJ (1990) Dietary regulation of fibrinolytic factors. Atherosclerosis $84: 25-32$

63. Huisveld IA, Leenen R, vdKooy K, Hospers JEH, Seidell JC, Deurenberg P, Koppeschaar HPF, Mosterd WL, Boupma BN (1990) Body composition and weight reduction in relation to antigen and activity of plasminogen activator inhibitor (PAI-1) in overweight individuals. Fibrinolysis 4: 84-85

64. Simpson HCR, Mann JI, Meade TW, Chakrabarti R, Stirling Y, Woolf L (1983) Hypertriglyceridaemia and hypercoagulability. Lancet I: 786-789

65. Rosenthal M, Haskell WL, Solomon R, Widstrom A, Reaven G (1983) Demonstration of a relationship between the level of physical training and insulin stimulated glucose utilization in normal humans. Diabetes 32: $408-411$

66. Speiser W, Langer W, Pschaick A, Selmayr E, Ibe B, Nowacki PR, Muller-Bergaus G (1988) Increased blood fibrinolytic activity after physical exercise: comparative study in individuals with different sporting activities and in patients after myocardial infarction taking part in a rehabilitation sports program. Thromb Res 51: 543-555

67. Estelles A, Aznar J, Tormo G, Sapena P, Tormo V, Espana F (1989) Influence of a rehabilitation sports program on the fibrinolytic activity of patients after myocardial infarction. Thromb Res 55: 203-212

68. Gris JC, Schved JF, Aguilar-Martinez P, Arnaud A, Sanchez N (1990) Impact of physical training on plasminogen activator inhibitor activity in sedentary men. Fibrinolysis 4:97-98

69. Loskutoff DJ, van Mourik JA, Erickson LA, Lawrence D (1983) Detection of an unusually stable fibrinolytic inhibitor produced by bovine endothelial cells. Proc Natl Acad Sci USA 80: 29562960

70. Sprengers ED, Princen HMG, Kooistra T, van Hinsberg VWM (1985) Inhibition of plasminogen activators by conditioned medium of human hepatocytes and hepatoma cell line HepG2. J Lab Clin Med 105: 751-758

71. Alessi MC, Juhan-Vague I, Kooistra T, Declerck PJ, Collen D (1988) Insulin stimulates the synthesis of plasminogen activator 
inhibitor 1 by the human hepatocellular cell line HepG2. Thromb Haemostas 60: 491-494

72. Kooistra T, Bosma P, Tons H, van den Berg A, Meyer P, Princen H (1989) Plasminogen activator inhibitor 1: biosynthesis and mRNA levels are increased by insulin in cultured human hepatocytes. Thromb Haemostas 62: 723-728

73. Anfosso F, Alessi MC, Latron Y, Juhan-Vague I (1990) IGF-1 increases PAI-1 synthesis by human hepatoma cell line HEPG2. Fibrinolysis 4 [Suppl.3]: 175 (Abstract)

74. Grant PJ, Kruithof EKO, Felley CP, Felber JP, Bachmann F (1990) Short-term infusions of insulin, triacylglycerol and glucose do not cause acute increases in plasminogen activator inhibitor 1 concentrations in man. Clin Sci 79: 513-516

75. Potter van Loon BJ, de Bart ACW, Radder JK, Frolich M, Kluft C, Meinders AE (1990) Acute exogenous hyperinsulinaemia does not result in elevation of plasma plasminogen activator inhibitor 1 (PAI-1) in humans. Fibrinolysis 4: 93-94

76. Juhan-Vague I, Vague P (1991) Hypofibrinolysis and insulin resistance. Diab Metab 17 [Suppl. 2]: 96-100

77. Kluft C, Jie AFH, Rijken DC, Verheijen JH (1988) Daytime fluctuations in blood of tissue-type plasminogen activator ( $\mathrm{t}-\mathrm{PA}$ ) and its fast acting inhibitor PAI-1. Thromb Hacmostas 59: 329-332

78. Medvescek M, Keber D, Stegnar M, Borovnicar A (1990) Plasminogen activator inhibitor 1 response to a carbohydrate meal in obese subjects. Fibrinolysis 4: 89-90
79. Williams JF, Olefsky JM (1990) Defective insulin receptor function in down-regulated HepG2 cells. Endocrinology 127: 17061717

80. Melin B, Cherqui G, Blivet MJ, Caron M, Lascols O, Capeau J, Picard J (1990) Dual effect of Metformin in cultured rat hepatocytes: Potentiation of insulin action and prevention of insulin-induced resistance. Metabolism 39: 1089-1095

81. Olefsky JM, Farquhar JW, Reaven GM (1974) Reappraisal of the role of insulin in hypertriglyceridemia. Am J Med 57: 551-560

82. Stiko-Rahm A, Wiman B, Hamsten A, Nilsson J (1990) Secretion of plasminogen activator inhibitor 1 from cultured human umbilical vein endothelial cells is induced by very low density lipoprotein. Arteriosclerosis 10: 1067-1073

83. Latron Y, Alessi MC, Anfosso F, Nalbonne G, Lafont H, JuhanVague I (1990) Effect of low density lipoproteins on secretion of plasminogen activator inhibitor 1 (PAI-1) by human endothelial cells and hepatoma cells. Fibrinolysis 4 [Suppl 2]: 82-83

Prof. I. Juhan-Vague

Laboratory of Haematology

CHU Timone

F-13385 Marseille Cedex 5

France 